\title{
STUDY OF EFFICACY AND SAFETY OF A NEW LOCAL CREAM (“HEALER”) IN THE TREATMENT OF CHRONIC ANAL FISSURE. A prospective, randomized, single-blind, comparative study
}

\author{
Mostafa YAKOOT ${ }^{1}$ and M. ABDEL SALAAM ${ }^{2}$
}

\begin{abstract}
Objectives - To determine the efficacy and safety of "healer" cream as monotherapy in the treatment of acute and chronic anal fissure. Study design - A prospective, randomized, single blinded, comparative trial. Methods - Sixty patients suffering from anal fissure were included in the study. Patients were randomly divided into three groups: group A: treated with "healer" local cream application 3 times daily; group B: treated with nitroglycerine $0.25 \%$ local cream 3 times daily; group C: treated with a lidocaine $2 \%$ cream applied locally 3 times daily. All the followings were followed up and compared between groups. (1) Visual pain analogue score after defecation; (2) severity of straining and discomfort during defecation; (3) frequency of ulcer healed at 30 days; (4) any side effects or complications. Results - The pain scoring after defecation was significantly reduced in the three treatment groups. The group treated with "healer" isosorbide-di-nitrate showed the greatest reduction of the visual pain analogue score median from 9 before treatment to $3 \& 1$ after 10 and 20 days respectively, while the median visual pain analogue score in group B treated with nitroglycerine cream was 9 reduced to $4 \& 2$ after 10 and 20 days respectively, and the median visual pain analogue score in lidocaine group only dropped from 9 to 6 and 4, respectively. The reduction of both pain scoring and defecation scoring with "healer" was statistically significantly greater than the other two treatments by Kruskal-Wallis test, $P<0.001$. The number of patients experiencing complete relief and passing stools easily after 10 days was significantly higher in "healer" group, by Pearson Chi square $=22.94, P<0.001$. After 30 days, the fissures were healed in $18(90 \%)$ of 20 patients in the "healer" group and in $12(60 \%)$ of 20 in the nitroglycerin group, while only $6(30 \%)$ of patients treated with lidocaine cream had their fissures healed by the 30 days treatment. Chi square $=15(P=$ 0.001). Conclusion - "Healer" is a promising effective and safe line of treatment in acute and chronic anal fissure. The characteristic pharmacokinetics of isosorbide-di-nitrate leads to a better effect than nitroglycerin in healing (more prolonged action). Also the less fast absorption than nitroglycerin leading to a smoother dose concentration curve, may be the cause that headache is less frequent and less severe in "healer" treatment versus nitroglycerin.
\end{abstract}

HEADINGS - Fissure in ano. Isosorbide dinitrate. Rutin.

\section{BACKGROUND}

Anal fissure is one of the most common and distressing disorders in ano-rectal region. It is a small tear in the anal skin just at or inside the anal verge. Typically it causes symptoms of severe pain after defecation and bright red rectal bleeding ${ }^{(2)}$.

It has been suggested that chronic anal fissure is ischemic in origin.

Patients with anal fissure typically have high resting anal pressures and infrequent spontaneous relaxation of the internal anal sphincter. These high anal pressures can impede the blood supply to the anoderm as it passes through the internal anal sphincter ${ }^{(1)}$. SCHOUTEN et al. ${ }^{(5)}$ had demonstrated in their study that anodermal blood flow at the posterior midline is less than in the other segments of the anal canal. The perfusion of the anoderm at the posterior commissure is strongly related to anal pressure. The higher the pressure, the lower the flow. These findings support the hypothesis that anal fissures are ischemic ulcers.

\section{RATIONALE}

Reduction of anal pressure, either by anal dilatation or by lateral internal sphincterotomy, is the most important step in the treatment of chronic anal fissure; however, both procedures frequently result in permanent sphincter defects and subsequent continence disturbances in about $30 \%$ of cases.

${ }^{1}$ Green Clinic; ${ }^{2}$ Anorectal Department, Alexandria Faculty of Medicine, Alexandria, Egypt.

Correspondence: Dr. Mostafa Yakoot, MD - Green Clinic, Alexandria, Egypt. E-mail: yakoot@yahoo.com 
Also the recurrence rates are about $16 \%$ and $7 \%$, respectively ${ }^{(6)}$.

Recently, nitric oxide (NO) has been identified as the chemical messenger mediating relaxation of the internal anal sphincter.

It has been shown that local application of exogenous NO donors such as nitroglycerin (GTN) and isosorbide-di-nitrate (ISDN) reduces anal pressure and improves anodermal blood flow. This dual effect results in fissure healing in more than $80 \%$ of patients in many clinical trials ${ }^{(6)}$.

Rutoside (Rutin), is a member of flavonoids which are compounds isolated from various plants that traditionally have been used for pain and vascular protection and for piles $^{(7)}$. It has been demonstrated that they reduce capillary filtration rate in patients with chronic venous insufficiency $(\mathrm{CVI})^{(3)}$; their effect on oedema reduction has also been confirmed $^{(4)}$.

"Healer" is a new topical cream based principally on isosorbide dinitrates $1 \%$, lidocaine $2 \%$, rutosides $5 \%$ in an antiseptic cream base.

\section{Objectives}

To study efficacy and safety of "healer" cream, as a monotherapy in the treatment of acute and chronic anal fissure.

\section{Study design} study.

A prospective, randomized, single blinded, comparative

\section{PATIENTS}

The study was conducted in the ano-rectal surgery departments in Alexandria Faculty of Medicine and in Karmoz Health Insurance Hospital. Between February 2003 and February 2005 patients presented with anal fissure were recruited to the study according to the following criteria.

Inclusion criteria

- Patients with acute anal fissure.

- Patients with chronic anal fissure with or without associated piles.

- Adult age between 18 and 60 years old.

Exclusion criteria

- Patients with Crohn's disease or malignancy.

- Pregnant females.

\section{INTERVENTIONS}

The study protocol was approved by the research ethics committee, and all participants provided written informed consent.

All patients were subjected to thorough history taking and physical examination, before the start of therapy and followed up throughout 30 days.

Patients were randomly divided into 3 groups:

- group A: treated with "healer" local cream applied 3 times daily;

- group B: treated with nitroglycerine $0.25 \%$ local cream 3 times daily.
- group C: treated with lidocaine $2 \%$ in emollient base applied 3 times daily.

All the followings were followed up and compared between groups:

- visual pain analogue score after defecation;

- straining and discomfort during defecation;

- frequency of fissures healed after 30 days treatment;

- any reported side effects or complications.

\section{RESULTS}

Sixty patients had completed the study protocol and their results were eligible for data analysis. They included 32 males and 28 females. The mean age of male group was 30.09 ( \pm 11.29), while the mean age of female group was $23.36( \pm$ 4.42). Table 1 shows the mean age in each sex.

TABLE 1. Age and sex distribution in the sample

\begin{tabular}{ccccc}
\hline Sex & $\mathbf{n}$ & Mean age & Std. deviation & Std. error mean \\
\hline male & 32 & 30.09 & 11.029 & 1.950 \\
female & 28 & 23.36 & 4.424 & .836 \\
\hline
\end{tabular}

Kolmogorov-Smirnov test for normality of distribution was done and showed that the distribution of both ordinal variables: visual pain analogue score (VPAS) and the score of ease of defecation were not normal. So we resorted to non parametric statistical methods for analysis of our results, and we took the median as the measure of central tendency.

The median VPAS scoring after defecation was significantly reduced in the three active treatment groups by Friedman k-related samples test $P<0.001$.

The group treated with "healer" (ISDN) showed the greatest reduction of VPAS median from 9 before treatment to $3 \& 1$ after 10 and 20 days respectively, while the median VPAS in group B treated with nitroglycerine cream was 9 reduced to $4 \& 2$ after 10 and 20 days respectively, and the median VPAS in lidocaine group only dropped from 9 to 6 and 4 respectively.

The difficulty and straining during defecation was categorized into three categories:

$(3=$ severe straining $-2=$ moderate straining $-1=$ passing easily).

Similar effects were found also on the degree of difficulty and straining in defecation; where the median score dropped from 3 before treatment to 1 after 10 days \& 1 after 20 days in both "healer" and nitroglycerine groups, and from 3 to 2 $\& 2$ respectively, in lidocaine group.

Table 2 is showing the results of both VPAS and defecation ease score before and after each treatment.

The reduction of both pain scoring and defecation scoring with "healer" was statistically significantly greater than the other two treatments by Kruskal-Wallis test, $P<0.001^{* *}$ (Table 3).

The frequency of categories of difficulty during defecation after 10 days of therapy is shown in Table 4 and Figure 1. The percentage of patients experiencing complete relief and 
Yakoot M, Abdel Salaam M. Study of efficacy and safety of a new local cream ("healer") in the treatment of chronic anal fissure. A prospective, randomized, single-blind, comparative study

TABLE 2. The effect of treatment on VPAS \& defecation ease scoring

\begin{tabular}{|c|c|c|c|c|c|}
\hline \multirow[b]{2}{*}{ Treatment } & \multirow[b]{2}{*}{ Variables } & \multirow[b]{2}{*}{$\mathrm{n}$} & \multicolumn{3}{|c|}{ Percentiles } \\
\hline & & & 25 th & $\begin{array}{c}50 \text { th } \\
\text { (median) }\end{array}$ & 75th \\
\hline \multirow[t]{6}{*}{ "Healer" } & VPAS before treatment & 20 & 9.00 & 9.00 & 9.00 \\
\hline & VPAS after $10 \mathrm{~d}$ & 20 & 2.00 & 3.00 & 3.00 \\
\hline & VPAS after $20 \mathrm{~d}$ & 20 & .25 & 1.00 & 1.00 \\
\hline & Defecation ease before treatment & 20 & 2.00 & 3.00 & 3.00 \\
\hline & Defecation ease after $10 \mathrm{~d}$ & 20 & 1.00 & 1.00 & 1.00 \\
\hline & Defecation ease after $20 \mathrm{~d}$ & 20 & 1.00 & 1.00 & 1.00 \\
\hline \multirow[t]{6}{*}{ GTN } & VPAS before treatment & 20 & 9.00 & 9.00 & 9.75 \\
\hline & VPAS after $10 \mathrm{~d}$ & 20 & 3.00 & 4.00 & 4.00 \\
\hline & VPAS after $20 \mathrm{~d}$ & 20 & 2.00 & 2.00 & 3.00 \\
\hline & Defecation ease before treatment & 20 & 2.00 & 3.00 & 3.00 \\
\hline & Defecation ease after $10 \mathrm{~d}$ & 20 & 1.00 & 1.50 & 2.00 \\
\hline & Defecation ease after $20 \mathrm{~d}$ & 20 & 1.00 & 1.00 & 2.00 \\
\hline \multirow[t]{6}{*}{ Lidocaine } & VPAS before treatment & 20 & 9.00 & 9.00 & 10.00 \\
\hline & VPAS after $10 \mathrm{~d}$ & 20 & 5.00 & 6.00 & 7.00 \\
\hline & VPAS after $20 \mathrm{~d}$ & 20 & 3.00 & 4.00 & 5.00 \\
\hline & Defecation ease before treatment & 20 & 2.00 & 3.00 & 3.00 \\
\hline & Defecation ease after $10 \mathrm{~d}$ & 20 & 2.00 & 2.00 & 2.75 \\
\hline & Defecation ease after $20 \mathrm{~d}$ & 20 & 1.00 & 2.00 & 2.00 \\
\hline
\end{tabular}

TABLE 3. Test statistics ${ }^{\mathrm{a}, \mathrm{b}}$

\begin{tabular}{lcccccc}
\hline & $\begin{array}{c}\text { VPAS } \\
\text { before Rx }\end{array}$ & $\begin{array}{c}\text { VPAS } \\
\text { after 10 d }\end{array}$ & $\begin{array}{c}\text { VPAS } \\
\text { after 20 d }\end{array}$ & $\begin{array}{c}\text { Defecation } \\
\text { ease } \\
\text { before }\end{array}$ & $\begin{array}{c}\text { Defecation } \\
\text { ease after } \\
10 \mathrm{~d}\end{array}$ & $\begin{array}{c}\text { Defection } \\
\text { ease after } \\
20 \mathrm{~d}\end{array}$ \\
\hline Chi-square & 1.071 & 42.115 & 41.258 & .000 & 19.068 & 13.423 \\
Df & 2 & 2 & 2 & 2 & 2 & 2 \\
Asymp. Sig. & .585 & .000 & .000 & 1.000 & .000 & .001 \\
\hline $\begin{array}{l}\text { a. Kruskal-Wallis test } \\
\text { b. Grouping variable test }\end{array}$ & & & & & &
\end{tabular}

TABLE 4. Cross-tabulation of treatment group by defecation ease after 10 days of $\mathrm{Rx}$

\begin{tabular}{llcccc}
\hline \multirow{2}{*}{ Treatment } & & \multicolumn{2}{c}{ Defecation ease after 10 d } & \multirow{2}{*}{ Total } \\
\cline { 3 - 5 } & & $\begin{array}{c}\text { easy } \\
\text { defecation }\end{array}$ & $\begin{array}{c}\text { moderate } \\
\text { straining }\end{array}$ & $\begin{array}{c}\text { severe } \\
\text { difficulty }\end{array}$ & \\
\hline \multirow{2}{*}{ "Healer" } & Count & 17 & 3 & 0 & 20 \\
& $\%$ within treatment & $85.0 \%$ & $15.0 \%$ & $.0 \%$ & $100.0 \%$ \\
\multirow{2}{*}{ GTN } & Count & 10 & 10 & 0 & 20 \\
& $\%$ within treatment & $50.0 \%$ & $50.0 \%$ & $.0 \%$ & $100.0 \%$ \\
\multirow{2}{*}{ Lidocaine } & Count & 4 & 11 & 5 & 20 \\
\multirow{2}{*}{ Total } & $\%$ within treatment & $20.0 \%$ & $55.0 \%$ & $25.0 \%$ & $100.0 \%$ \\
& Count & 31 & 24 & 5 & 60 \\
& $\%$ within treatment & $51.7 \%$ & $40.0 \%$ & $8.3 \%$ & $100.0 \%$ \\
\hline
\end{tabular}

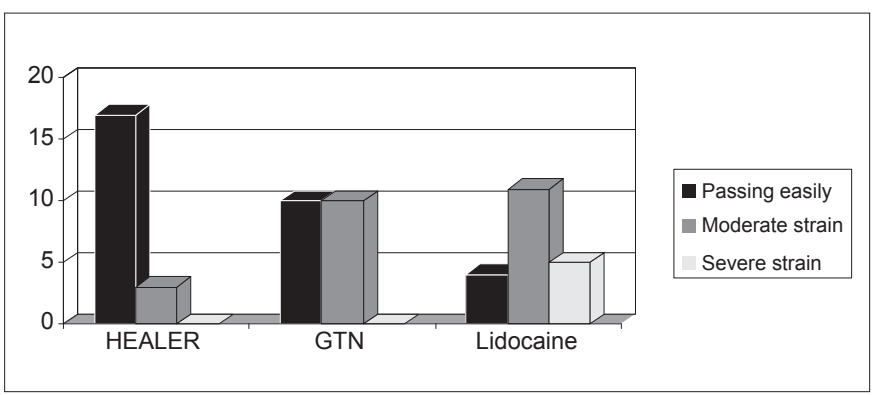

FIGURE 1. Effect of treatment on defecation difficulty after 10 days of treatment
TABLE 5. Cross-tabulation of treatment group by frequency of healing after 30days

\begin{tabular}{llccc}
\hline \multirow{2}{*}{ Treatment } & & \multicolumn{2}{c}{ Healing Freq. after 30 days } & \multirow{2}{*}{ Total } \\
\cline { 3 - 4 } & & Complete healing & $\begin{array}{c}\text { no complete } \\
\text { healing }\end{array}$ & \\
\hline "Healer" & Count & 18 & 2 & 20 \\
& \% within treatment & $90.0 \%$ & $10.0 \%$ & $100.0 \%$ \\
\multirow{2}{*}{ GTN } & Count & 12 & 8 & 20 \\
& \% within treatment & $60.0 \%$ & $40.0 \%$ & $100.0 \%$ \\
\multirow{2}{*}{ Lidocaine } & Count & 6 & 14 & 20 \\
\multirow{2}{*}{ Total } & \% within treatment & $30.0 \%$ & $70.0 \%$ & $100.0 \%$ \\
& Count & 36 & 24 & 60 \\
& \% within treatment & $60.0 \%$ & $40.0 \%$ & $100.0 \%$ \\
\hline
\end{tabular}

passing stools easily after 10 days was significantly higher in "healer" group, by Pearson chi square test; value $=22.94$. $P<0.0001^{* *}$

After 30 days, the fissures were healed in $18(90 \%)$ of 20 patients in the "healer" group and in $12(60 \%)$ of 20 in the nitroglycerin group, while only $6(30 \%)$ of patients treated with lidocaine cream had their fissures healed by the 30 days treatment. Chi square $=15(P=0.001)$.

Frequencies of complications and side effects are plotted in the Figure 2.

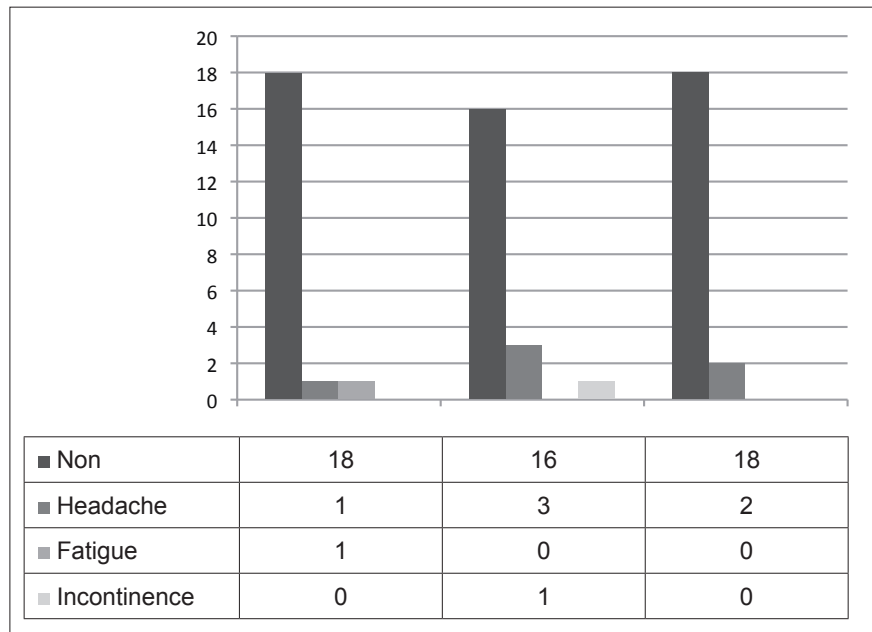

FIGURE 2. Frequencies of complications and side effects

No side effects were experienced in 18 out of 20 treated with "healer", while only transient mild headache was encountered by two patients.

\section{DISCUSSION}

Our results are in agreement with most researches in the literature as regards healing of the anal fissure which was better in the 2 nitrates arms with more percentage of healing after 30 days treatment with "healer" $(90 \%)$.

The most important causes that lead patient to seek medical advice are the severe pain after defecation and the 
very difficult straining and discomfort during defecation. Both symptoms were found to be significantly more responding to "healer" with faster onset of effect, this is most probably because the duration of action of ISDN is more prolonged to cover more hours of the day than GTN. Only a single case out of 20 cases treated with nitroglycerine had got mild transient incontinence. Headache was encountered in three cases in GTN group, and a milder headache was experienced in a two cases in "healer" group.

\section{CONCLUSION}

"Healer" is a promising effective and safe line of treatment in acute and chronic anal fissure. The characteristic pharmacokinetics of ISDN leads to a better effect than GTN in healing (more prolonged action). Also the less fast absorption than GTN leading to a smoother dose concentration curve, may be the cause that headache is less frequent and less severe in "healer" treatment.

Yakoot M, Abdel Salaam M. Estudo da eficácia e segurança de novo creme cicatrizante para o tratamento da fissura anal crônica. Estudo prospectivo, randomizado, simples-cego e comparativo. Arq Gastroenterol. 2009;46(3):179-82.

RESUMO - Objetivos - Determinar a eficácia e segurança de "creme cicatrizante" (dinitrato de isosorbida 1\%; lidocaína 2\%; rutosídios 5\% em base de creme anti-séptico) como monoterapia no tratamento da fissura anal aguda ou crônica. Metodologia - Estudo prospectivo, randomizado, simplescego, comparativo. Foram incluídos 60 pacientes com fissura anal. Foram divididos randomicamente em três grupos: grupo A: tratados com "creme cicatrizante", grupo B: tratados com creme de nitroglicerina 0,25\% e grupo C: tratados com creme de lidocaína $2 \%$ aplicado. Em todos foi feita aplicação local 3 vezes ao dia. Os seguintes parâmetros foram aferidos: 1) escore analógico visual de dor após defecação, 2) severidade de esforço e desconforto para evacuar, 3) frequência da cicatrização após 30 dias, 4) presença de efeitos colaterais ou complicações. Resultados - O escore de dor após a defecação foi reduzido significativamente nos três grupos. O grupo tratado com creme cicatrizante mostrou grande redução do escore médio de 9 para 3 e 1 após 10 e 20 dias de tratamento, respectivamente, enquanto que a média do grupo B foi reduzida de 9 para 4 e 2 e do grupo C de 9 para 6 e 4 após 10 e 20 dias de tratamento, respectivamente. A redução tanto da dor como do desconforto evacuatório com o uso de "creme cicatrizante" foi significativo em comparação com os outros cremes pelo teste de Kruskal-Wallis, $P<0,001$. O número de pacientes que referiram alívio completo e passagem fácil da fezes após 10 dias de tratamento foi maior e significativo no grupo A pelo teste Pearson, $P<0,001$. Após 30 dias, as fissuras estavam cicatrizadas em $18(90 \%)$ pacientes do grupo A, em $12(60 \%)$ do grupo B e em apenas $6(30 \%)$ do grupo C. Qui ao quadrado $=15(P$ = 0,001). Conclusãa - O "creme cicatrizante" é um tratamento que promete ser promissor e seguro na fissura anal aguda ou crônica. A característica farmacocinética do creme leva a um melhor efeito que a nitroglicerina quanto a cicatrização (ação mais prolongada). Possivelmente cause menos cefaléia que a nitroglicerina devido a sua absorção ser mais lenta e causar uma curva de concentração mais suave do medicamento.

DESCRITORES - Fissura anal. Dinitrato de isossorbida. Rutina.

\section{REFERENCES}

1. Farouk R, Duthie GS, MacGregor AB, Bartolo DC. Sustained internal sphincter hypertonia in patients with chronic anal fissure. Dis Colon Rectum. 1994;37:424-9.

2. Madoff RD. Pharmacologic therapy for anal fissure. N Engl J Med. 1998;338: 257-9.

3. Roztocil K, Prerovsky I. The effect of 7-monohydroxyethylrutoside on capillary filtration rate in the lower limb of man. In: Davy A, Stemmer R, ed. Phlébologie '89: actes du 10e Congrès Mondiale, Union Internationale de Phlébologie, Strasbourg, 25-29 septembre, 1989. London: John Libbey; 1989. p.719-21.

4. Rudofsky G, Diehm C, Grub J, Hartmann M, Schultz-Ehrenburg HU, Bisler H. Ruscus saponines and the flavanoid hesperidinmethylchalcone in the treatment of chronic venous insufficiency. In: Davy A, Stemmer R, ed. Phlébologie '89: actes du 10e Congrès Mondiale, Union Internationale de Phlébologie, Strasbourg 25-29 septembre, 1989. London: John Libbey; 1989. p.728-30.

5. Schouten WR, Briel JW, Auwerda JJ. Relationship between anal pressure and anodermal blood flow. The vascular pathogenesis of anal fissures. Dis Colon Rectum. 1994;37:664-9

6. Schouten WR, Briel JW, Auwerda JJ, Boerma MO. Anal fissure: new concepts in pathogenesis and treatment. Scand J Gastroenterol. 1996(Suppl 218):78-81.

7. Wadworth AN, Faulds D. Hydroxyethylrutosides. A review of its pharmacology, and therapeutic efficacy in venous insufficiency and related disorders. Drugs. 1992;44:1013-32. 